\title{
Anesthesia interventions that alter perioperative mortality: a scoping review
}

\author{
Sylvain Boet ${ }^{*}$ (D), Cole Etherington ${ }^{2}$ (D), David Nicola ${ }^{3}$, Andrew Beck ${ }^{4}$, Susan Bragg ${ }^{5}$, lan D. Carrigan ${ }^{6}$, \\ Sarah Larrigann ${ }^{6,7}$, Cassandra T. Mendonca ${ }^{1}$ I Isaac Miao ${ }^{1}$, Tatyana Postonogova ${ }^{8}$, Benjamin Walker ${ }^{9}$, José De Wit ${ }^{1}$, \\ Karim Mohamed ${ }^{1}$, Nadia Balaa ${ }^{10}$, Manoj Mathew Lalu ${ }^{11,12}$, Daniel I Mclsaac ${ }^{1,13}$, David Moher ${ }^{2}$, Adrienne Stevens ${ }^{2}$, \\ Donald Miller ${ }^{1}$ and On behalf of the Perioperative Anesthesia Clinical Trials Group (PACT)
}

\begin{abstract}
Background: With over 230 million surgical procedures performed annually worldwide, better application of evidence in anesthesia and perioperative medicine may reduce widespread variation in clinical practice and improve patient care. However, a comprehensive summary of the complete available evidence has yet to be conducted. This scoping review aims to map the existing literature investigating perioperative anesthesia interventions and their potential impact on patient mortality, to inform future knowledge translation and ultimately improve perioperative clinical practice.

Methods: Searches were conducted in MEDLINE, EMBASE, CINAHL, and the Cochrane Library databases from inception to March 2015. Study inclusion criteria were adult patients, surgical procedures requiring anesthesia, perioperative intervention conducted/organized by a professional with training in anesthesia, randomized controlled trials (RCTs), and patient mortality as an outcome. Studies were screened for inclusion, and data was extracted in duplicate by pairs of independent reviewers. Data were extracted, tabulated, and reported thematically.

Results: Among the 10,505 publications identified, 369 RCTs ( $n=147,326$ patients) met the eligibility criteria. While 15 intervention themes were identified, only 7 themes (39 studies) had a significant impact on mortality: pharmacotherapy $(n=23)$, nutritional $(n=3)$, transfusion $(n=4)$, ventilation $(n=5)$, glucose control $(n=1)$, medical device $(n=2)$, and dialysis $(n=1)$.

Conclusions: By mapping intervention themes, this scoping review has identified areas requiring further systematic investigation given their potential value for reducing patient mortality as well as areas where continued investment may not be cost-effective given limited evidence for improving survival. This is a key starting point for future knowledge translation to optimize anesthesia practice.
\end{abstract}

Keywords: Anesthesiology, Mortality, Review

\section{Background}

Rationale

With more than 230 million major surgical procedures performed annually worldwide [1], better application of evidence in anesthesia and perioperative medicine has the potential to significantly improve patient safety, care, and satisfaction [2, 3]. Currently, as with many other

\footnotetext{
* Correspondence: sboet@toh.ca

'Department of Anesthesiology and Pain Medicine, The Ottawa Hospital, University of Ottawa, General Campus, 501 Smyth Rd, Critical Care Wing 1401, Ottawa, Ontario K1H 8L6, Canada

Full list of author information is available at the end of the article
}

specialities, anesthesiologists have large variations in practice and patient outcomes [4-7], with many examples of failure to follow best practices $[8,9]$. For instance, the maintenance of perioperative normothermia has been shown to decrease the rate of surgical site infection by threefold [10-15]. However, while effective tools for maintaining normothermia exist, perioperative hypothermia continues to affect up to $20 \%$ of patients [15].

Clearly, the mere existence of best clinical evidence does not mean that it will be adopted into practice or improve patient outcomes [16]. Knowledge translation (KT) $[17,18]$ focuses on the effective implementation of

(c) The Author(s). 2018 Open Access This article is distributed under the terms of the Creative Commons Attribution 4.0 International License (http://creativecommons.org/licenses/by/4.0/), which permits unrestricted use, distribution, and reproduction in any medium, provided you give appropriate credit to the original author(s) and the source, provide a link to the Creative Commons license, and indicate if changes were made. The Creative Commons Public Domain Dedication waiver (http://creativecommons.org/publicdomain/zero/1.0/) applies to the data made available in this article, unless otherwise stated. 
best clinical practices, moving evidence to practice [19]. In anesthesiology, there have been few previous attempts to summarize comprehensively the broader peer-reviewed literature and those articles which have been published face methodological limitations [20, 21]. A comprehensive summary of the complete available evidence related to mortality has yet to be conducted.

Scoping reviews have been specifically described as a process of mapping the existing evidence, by providing a comprehensive and thorough review of the available literature [22]. They are particularly useful for complex fields, such as anesthesiology and perioperative medicine [23]. Unlike systematic reviews, scoping reviews summarize a range of evidence in order to convey the breadth and depth of evidence in a certain field [23]. In addition, scoping studies differ from systematic reviews because they address broad research questions and do not typically quantify the effect of interventions [24, 25]. Instead, a scoping review examines the extent, range, nature, and characteristics of the primary research and summarizes the evidence [22]. Scoping reviews are often preliminary to full systematic reviews when the field of research is broad and complex, such as anesthesiology and perioperative medicine, making the feasibility of a systematic review a concern because the potentially relevant literature is thought to be especially vast and diverse.

\section{Methods}

This scoping review is reported according to the PRISMA Extension for Scoping Reviews (PRISMA-ScR) Checklist [26]. We also followed the current framework developed by Arksey and O'Malley [22] and Levac et al. [27] in conducting this review. In order to achieve the purposes of the scoping review, we employed a five-stage framework: (1) identify the research question, (2) identify relevant published studies, (3) refine the study selection criteria, (4) collect the relevant data from each published article, and (5) collate, summarize, report, and interpret the results.

\section{Objectives}

Based on the existing gaps in the literature, we asked the following research question: What types of anesthesiarelated interventions impact patients' mortality?

\section{Eligibility criteria}

Based on the existing gaps in the literature, we asked the following research question: What types of anesthesi a-related interventions impact patients' mortality? We selected all articles published in journals that involved adult patients ( $\geq 16$ years old) undergoing surgery and that evaluated an anesthesia-related intervention. Anesthesia-related interventions were defined as interventions provided in the perioperative period that either were, or could have been, performed, organized, or initiated by a healthcare professional with specific training in anesthesia. For example, the following interventions were included: perioperative administration of antibiotherapy [28], intraoperative remote ischemic preconditioning [29], and postoperative ventilation support [30]. Furthermore, studies involving surgical procedures involving local anesthesia only were excluded, as well as studies reporting perioperative interventions that are exclusively interested in comparing different surgical techniques (e.g., laparoscopic versus open surgery). The perioperative period referred to the time window from the initial preoperative anesthesia assessment before the surgery to the final care provided or organized by anesthesia providers following surgery. Therefore, the perioperative period was separated into three distinct phases: preoperative, intraoperative, and postoperative. We focused on the studies assessing mortality as an outcome and included randomized controlled trials (RCTs). The comparator group of the RCT was defined as either no treatment or usual standard of care. We did not impose a minimum sample size for included studies.

\section{Information sources and search strategy}

The initial search strategy was developed with the active contribution of experts in the methodology of conducting reviews (AS), a practicing anesthesiologist (SB), and a health sciences librarian (LAH).

The electronic databases MEDLINE, EMBASE, CINAHL, and the Cochrane Library were searched. Literature searches were performed without any language restrictions, but we only included articles published in English. The literature search was performed on March 5, 2015, without any year restriction. The MEDLINE search strategy underwent Peer Review of Electronic Search Strategies (PRESS) by a second trained information scientist $[31,32]$. Search strategies can be found in Additional file 1. Reference lists of relevant systematic reviews were also searched to identify additional relevant studies. The final list of the included studies was also reviewed by the Perioperative Anesthesia Clinical Trials Group (PACT) for both completeness and relevance.

\section{Selection of sources of evidence}

The identified articles were merged into the web-based systematic review software DistillerSR (Evidence Partners, Ottawa, Canada), and duplicates were removed. The screening tools were developed by the research team and piloted with a subset of articles for refinement and reviewer calibration. Reviewers were trained on how to use DistillerSR (Evidence Partners, Ottawa, Canada) and to critically appraise articles according to the inclusion and exclusion criteria of this scoping review. 
Articles were screened for eligibility by title and abstract by two individuals using the liberal accelerated screening approach [33]. This approach involved one reviewer screening citations by title and abstract using the screening tool based on the predetermined criteria. The selected studies classified as either "included" or "unclear" advanced to the subsequent screening stage. However, studies classified as "excluded," were reviewed by the other reviewer to determine whether the exclusion criteria were properly met.

Following the completion of the title and abstract screening stage, the full texts of all qualified studies were reviewed in duplicate by six pairs of independent reviewers (DN, AB, SB, IC, CM, IM, TP, BW, SL, KM, JDW, $\mathrm{NB})$ for compliance with eligibility criteria. Disagreements were resolved by consensus or referred to a third member of the research team for resolution. The list of included articles was reviewed by the investigators to determine if any additional articles should be included [34].

The accuracy of the included and excluded studies was verified using the artificial intelligence feature of DistillerSR (Evidence Partners, Ottawa, Canada).

\section{Data charting process}

A data extraction form was created and piloted by the research team. Six pairs of reviewers $(\mathrm{DN}, \mathrm{AB}, \mathrm{SB}, \mathrm{IC}$, CM, IM, TP, BW, SL, KM, JDW, NB) independently extracted the study characteristics and the mortality outcome from the included studies. We collected information on publication details (e.g., first author's name, year of publication, study location) and information about the study details (e.g., study design; sample size; gender; age; ASA score; intervention details, such as duration and type; setting; perioperative phase; anesthesia type; comparator; and mortality outcome details, such as timing). The significance of the intervention on mortality is reported according to how it was defined by the study authors.

Where data was inadequately reported within the full-text article, we contacted the original authors for clarification and further details. Quality assessments of included studies were not reported because they are typically not completed during the scoping reviews [22].

\section{Data items}

This scoping review allowed for the development of anesthesia-related intervention themes that outline what evidence levels currently exist as well as the potential gaps in anesthesia research that may be further explored. Interventions were classified according to these themes and defined in Additional file 2. A list of themes was determined a priori, and reviewers could add new themes when a study did not fit any a priori theme.

\section{Synthesis of results}

The results of this scoping review were synthesized using both a numerical summary outlining the relevant characteristics of the included studies and a narrative synthesis interpreting the results (Additional files 3 and 4).

\section{Results \\ Study selection}

The literature search strategy yielded a total of 10,505 references, of which 1270 were duplicates. Nine additional studies were identified: eight from the reference list of a relevant systematic review and one identified by experts. After screening, 8768 references were excluded. A total of 369 references met the inclusion criteria (Fig. 1). The AI feature on DistillerSR (Evidence Partners, Ottawa, Canada) confirmed that all inclusions and exclusions were correct (i.e., the AI system did not identify any articles erroneously included or excluded by the human screeners).

\section{Study characteristics}

Details of the included study characteristics, participants, type of surgery, study design, and interventions are provided in Additional file 1. Of the 369 studies, 331 indicated data collection occurred in a single country. These locations are displayed in Fig. 2. One study did not report country of data collection. The remaining 37 studies indicated data collection was performed in more than one country. The largest number of trials was conducted in the USA $(n=69)$. Multicenter trials were conducted in 102 studies, with the remainder involving a single center. The 369 trials included a total of 147,326 participants (median 123, IQR 60-272).

\section{Anesthesia-related intervention theme, type of surgery and perioperative phase}

The most common anesthesia-related intervention theme found was pharmacotherapy (201 included studies [54\%]; 104,413 patients [71\%]) followed by nutritional interventions (28 studies [8\%]; 5191 patients [4\%]) (Table 1). Most studies ( $n=180$ studies [49\%]; $n=95,119$ patients [65\%]) involved interventions spanning more than one perioperative phase (i.e., various combinations of preoperative, intraoperative, and postoperative phases) (Table 2). The most common type of surgery reported was cardiac surgery $(n=151$ studies [41\%]; $n=63,738$ patients [43\%]), followed by general surgery $(n=66$ studies [18\%]; $n=13,458$ patients [9\%]) and vascular surgery ( $n=31$ studies [8\%]; $n=6404$ patients $[4 \%]$ ).

\section{Mortality outcome of anesthesia-related interventions}

The vast majority of included studies showed no statistically significant effect on mortality $(n=330$ [89\%] studies; $n=117,905$ [80\%] patients). 


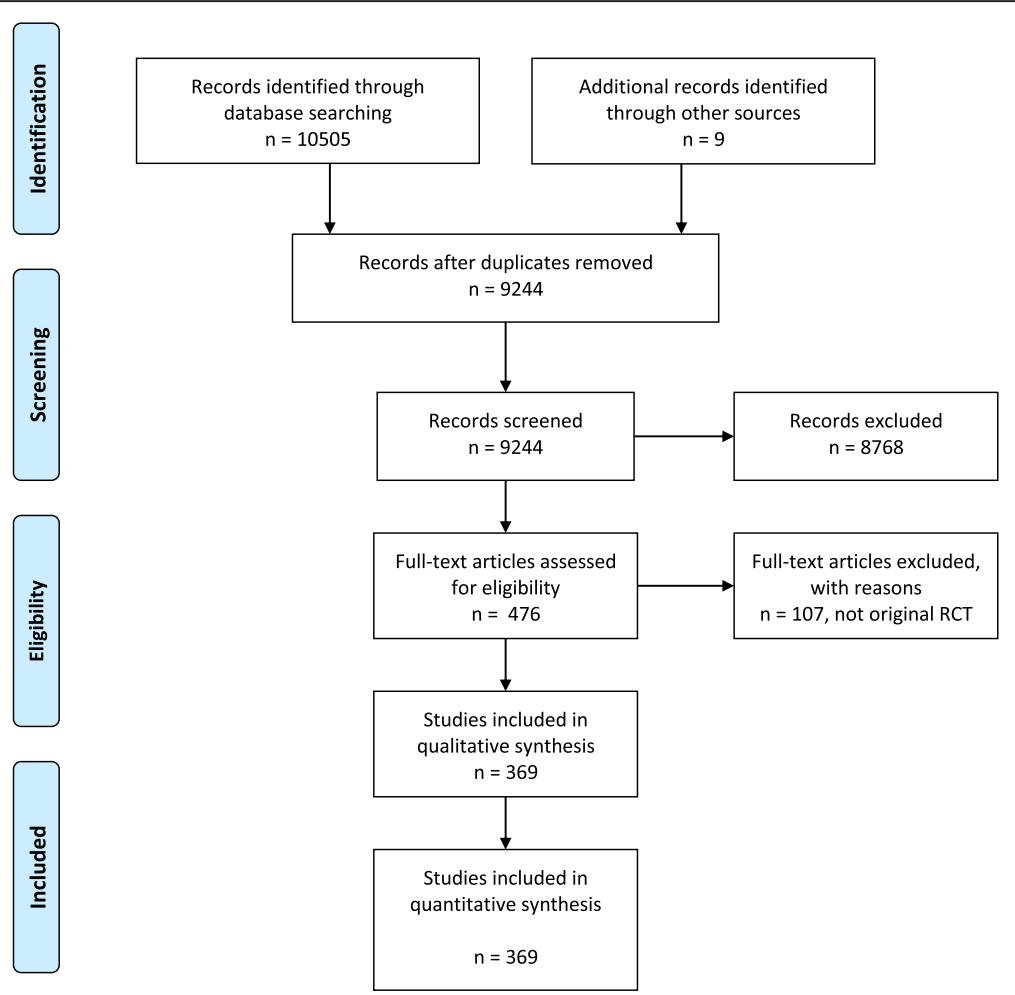

Fig. 1 PRISMA diagram

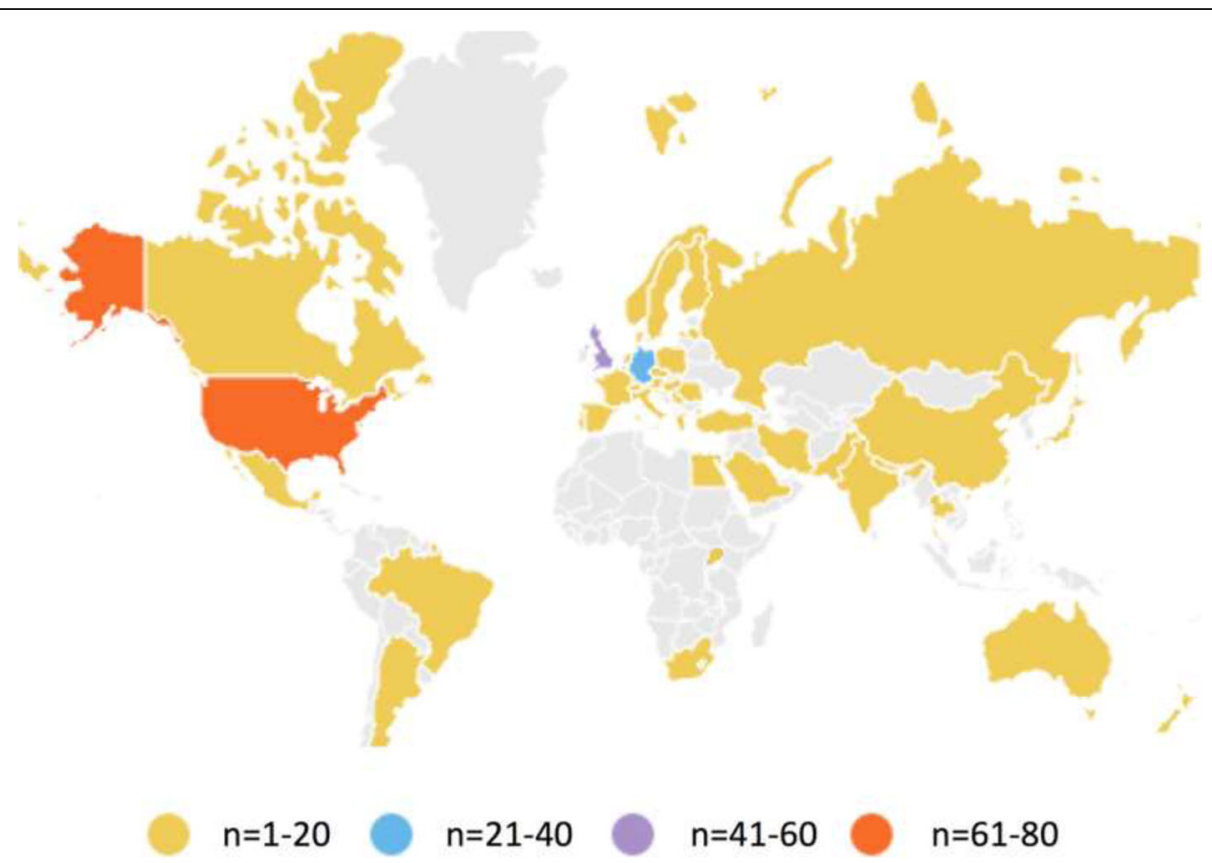

Fig. 2 Country of data collection for anesthesia-related interventions 
Table 1 Anesthesia-related intervention themes by number of studies and patients

\begin{tabular}{lll}
\hline $\begin{array}{l}\text { Intervention } \\
\text { category }\end{array}$ & $\begin{array}{l}\text { Number } \\
\text { of studies }\end{array}$ & $\begin{array}{l}\text { Number } \\
\text { of patients }\end{array}$ \\
\hline Anesthetic technique & 13 & 2445 \\
Dialysis & 1 & 44 \\
Glucose control & 6 & 2139 \\
IV fluids & 13 & 1869 \\
Medical device & 21 & 5233 \\
Monitoring & 4 & 3341 \\
Nutritional & 28 & 5191 \\
Pharmacotherapy & 207 & 104,413 \\
Physiotherapy & 2 & 283 \\
Preoperative procedure & 1 & 510 \\
Protocol/guidelines implementation & 22 & 2705 \\
Temperature management & 4 & 2444 \\
Testing & 2 & 1566 \\
Transfusion & 23 & 8747 \\
Ventilation & 18 & 5469 \\
Combination of interventions & 4 & 927 \\
Total & 369 & 147,326 \\
\hline
\end{tabular}

Only 39 studies (11\%) representing 29,421 patients (20\%) reported a significant difference in mortality, with either a decrease $(n=30$ [77\%] "significant" studies; $n=10,660$ [36\%] patients), an increase $(n=8$ [21\%] studies; $n=18,459$ [63\%] patients), or both depending on the time at which mortality was measured ( $n=1$ [3\%] study; $n=302$ [1\%] patients). The following intervention themes were represented: pharmacotherapy $\quad(n=23 \quad[59 \%] \quad$ studies; $n=23,322 \quad[79 \%]$ patients), nutritional ( $n=3[8 \%]$ studies; $n=797[3 \%]$ patients), transfusion ( $n=4[10 \%]$ studies; $n=1558$ [5\%] patients), ventilation ( $n=5$ [13\%] studies; $n=$ 1602 [5\%] patients), medical device $(n=2$ [5\%] studies; $n=550$ [2\%] patients), dialysis-related $(n=1$ [3\%] study; $n=44$ [0.1\%] patients), and glucose control ( $n=1$ [3\%] study; $n=1548$ [5\%] patients).

Table 2 Perioperative phase of anesthesia-related interventions according to the number of studies and patients

\begin{tabular}{lll}
\hline Perioperative phase & $\begin{array}{l}\text { Number } \\
\text { of studies }\end{array}$ & $\begin{array}{l}\text { Number } \\
\text { of patients }\end{array}$ \\
\hline Preoperative & 25 & 6139 \\
Intraoperative & 101 & 24,824 \\
Postoperative & 62 & 20,964 \\
Multiphase (i.e., intervention & 180 & 95,119 \\
spanned across 2 or 3 phases) & & 280 \\
Not reported & 1 & 147,326 \\
\hline Total & 369 & \\
\hline
\end{tabular}

\section{Interventions that impact survival}

Only seven themes were represented among the anesthesia interventions that were associated with altered mortality rates (Fig. 3). For each intervention theme, we discuss only those studies that reported a statistically significant effect on patient mortality.

\section{Pharmacotherapy interventions}

As shown in Table 3, a total of 23 publications (23,322 patients) were identified for anesthesia-related pharmacotherapy interventions which significantly impacted mortality. Of these studies, 6 (26\%) reported an increase in mortality $(n=17,050$ [73\%] patients) while $17(74 \%)$ reported a decrease in mortality $(n=6272$ [27\%] patients). Most studies that reported a significant impact on mortality ( $n=15$ [65\%]; $n=13,368$ [57\%] patients) reported mortality as a primary outcome. The most frequent type of surgery involved was cardiac $(n=10$ [43\%]; $n=12,045$ [52\%] patients). Pharmacotherapy interventions involved a wide variety of pharmacotherapy and dosing regimens, with the interventions most commonly occurring across more than one surgical phase $(n=18$ [78\%]; $n=13,302$ [57\%] patients).

\section{Nutritional interventions}

Table 4 reports the three nutritional interventions $(n=$ 797 patients), identified as having a significant impact on mortality. Of these studies, one (33\%) reported an increase in mortality ( $n=27$ [3\%] patients) [35], one (33\%) reported a decrease in mortality ( $n=468$ [59\%] patients) [36], and one (33\%) reported an increase in mortality in-hospital, but a decrease in deaths occurring at 4 months ( $n=302$ [38\%] patients) [37]. Each study implemented a distinct nutritional intervention, and each involved a different field of surgery (thoracic, orthopedic, cardiac, colorectal). Mortality was reported as a primary outcome in two of the studies, with both finding an increase in mortality. Of the three different nutritional interventions, two were given pre- and postoperatively and one was given postoperatively only.

\section{Transfusion interventions}

As shown in Table 5, four transfusion interventions demonstrated a significant decrease in mortality $(n=1558$ patients). Two studies involved transfusion of leuko-depleted red blood cells during cardiac surgery [38, 39]. Each study assessed mortality as a secondary outcome, either in-hospital or until 60 days following surgery. Another study [40] involved orthopedic surgery and the perioperative transfusion of hemoglobin at a threshold of $10.0 \mathrm{~g} / \mathrm{dL}$. Mortality was assessed as a secondary outcome at 30 days. The final study [41] involved pre- and postoperative administration of subcutaneous erythropoietin ( $\mathrm{r}-\mathrm{HuEPO}$ at $300 \mathrm{IU} / \mathrm{kg}$ ) plus IV iron (100 mg). Survival at 1 year was 


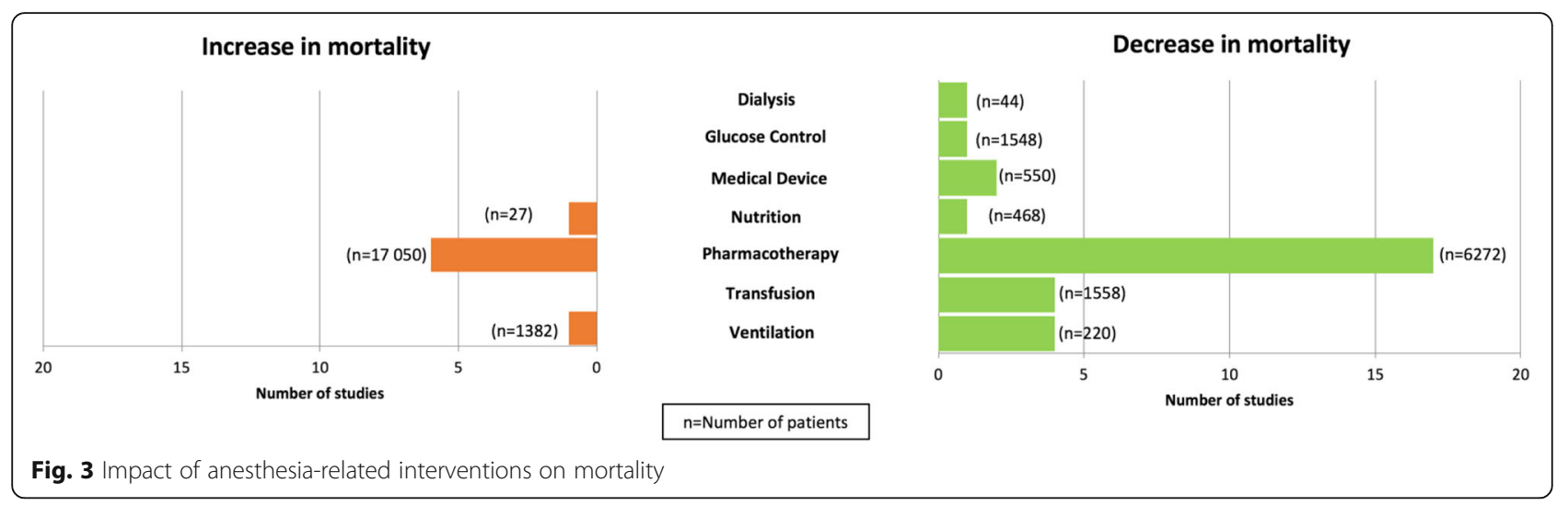

assessed, but it was not reported whether this was a primary or secondary outcome.

\section{Ventilation interventions}

Five ventilation interventions ( $n=1602$ patients) had a statistically significant impact on mortality. Two were administered intraoperatively and postoperatively [42, 43], and three were administered only postoperatively $[30,44,45]$ (Table 6). Non-invasive ventilation decreased in-hospital mortality in three studies $(n=183$ [11\%] patients) $[30,44,45]$. It was also found by one study to decrease mortality at 120 days [30]. The intervention which decreased mortality at 60 days $(n=37$ [2\%] patients) involved intentionally increasing oxygen delivery to $>600 \mathrm{ml} / \mathrm{min} / \mathrm{m}^{2}$ [42]. The intervention which increased mortality at 2 years $(n=1382$ [86\%] patients) involved giving patients an $\mathrm{FiO}_{2}$ of 0.80 after intubation and for $2 \mathrm{~h}$ after surgery [43]. All but one study [30] assessed mortality as a primary outcome.

\section{Other significant interventions}

Four studies investigating three other anesthesia-related interventions that statistically significantly impacted mortality are shown in Table 7 ( $n=2142$ patients). These included use of a device $(n=2$ [50\%], $n=550$ [26\%] patients) [46, 47], dialysis ( $n=1$ [25\%], $n=44$ [2\%] patients) [48], and glucose control ( $n=1$ [25\%], $n=1548$ [72\%] patients) [49]. Intraoperative devices significantly decreased mortality in-hospital, at 30 days and at 1 year for patients who underwent cardiac surgery. Mortality was assessed as a secondary outcome in one study [46], while the other did not report whether it was a primary or secondary outcome [47]. The dialysis intervention was implemented pre- and postoperatively, involved cardiac surgery, and showed decreased in-hospital mortality. It was not specified whether mortality was considered a primary or secondary outcome. Finally, the glucose control intervention was implemented postoperatively, did not report the type of surgery, and decreased mortality (primary and secondary outcome).

\section{Discussion}

This scoping review presents the current evidence relevant to anesthesiologists and policy-makers, highlighting anesthesia-related evidence-based interventions that impact the mortality of adult surgical patients $(n=39$ RCTs; 29,421 patients). By identifying the nature and distribution of studies as well as the potential value of various anesthesia-related interventions for reducing mortality, this review can be used to identify future directions for perioperative research to translate evidence into practice and improve standardization of care.

Among the 15 themes of anesthesia-related interventions identified, only 7 themes demonstrated a significant impact on mortality: pharmacotherapy, nutrition, transfusion, glucose control, device, dialysis, and ventilation. Each of these themes (with the exception of dialysis) was also identified by Landoni et al. in a recently updated consensus on randomized evidence for the reduction of perioperative mortality [50]. The consensus process followed the first systematic review of RCTs on non-surgical interventions with mortality differences in the operative period [21]. It is therefore a strength of our study to confirm the findings of Landoni et al. [21, 50] and to build upon this important foundation in perioperative research. We also included studies with non-significant findings in our review, which are important for practitioners to consider.

Within the identified anesthesia-related intervention themes, 39 studies $(29,421$ patients) demonstrated an impact on mortality, either positive or negative. Of the 30 studies where the implemented intervention decreased mortality, 17 involved pharmacotherapies. Thus, pharmacotherapy interventions may have a great potential to reduce mortality among surgical patients. It is interesting to note that the importance of pharmacotherapy on mortality was also found by Landoni et al. [50]. Although they used a different methodology and categorized interventions into different themes, Landoni et al. also found over half of the themes (7/13) related closely to pharmacotherapy. Thus, future research may investigate the 
Table 3 Summary of mortality outcome for pharmacotherapy interventions for a significant difference in mortality

\begin{tabular}{|c|c|c|c|c|}
\hline First author, year & $\begin{array}{l}\text { Type of surgery, } \\
\text { no. of participants }\end{array}$ & Intervention/comparison details & $\begin{array}{l}\text { Perioperative phase, } \\
\text { duration of intervention }\end{array}$ & $\begin{array}{l}\text { Impact on mortality* } \\
\text { (outcome definition, } \\
\text { timing) }\end{array}$ \\
\hline Aronson, 2008 & Cardiac, 1506 & $\begin{array}{l}\text { IV clevidipine at an initial rate of } 0.4 \mathrm{mcg} / \mathrm{kg} / \mathrm{min} \text {, } \\
\text { titrating to antihypertensive effect to a max } \\
\text { dose of } 8 \mathrm{mcg} / \mathrm{kg} / \mathrm{min} \text {. } \\
\text { Three comparator groups of common } \\
\text { (usual care) perioperative antihypertensives: } \\
\text { nitroglycerin, sodium nitroprusside, } \\
\text { and nicardipine. }\end{array}$ & $\begin{array}{l}\text { Preoperative, } \\
\text { intraoperative, } \\
\text { postoperative } \\
\text { Once }\end{array}$ & $\begin{array}{l}\text { Decreased mortality } \\
\text { (death at } 30 \text { days, } \\
\text { primary outcome) }\end{array}$ \\
\hline Boyd, 1993 & $\begin{array}{l}\text { Major surgery, } \\
107\end{array}$ & $\begin{array}{l}\text { Dopexamine infusion to achieve oxygen } \\
\text { delivery }\left(\mathrm{DO}_{2} \mathrm{l}\right) \text { of greater than } 600 \mathrm{~mL} / \mathrm{min} / \mathrm{m}^{2} \text {, } \\
\text { perioperatively, in high-risk patients. } \\
\text { Usual care }\end{array}$ & $\begin{array}{l}\text { Preoperative, } \\
\text { intraoperative, } \\
\text { postoperative } \\
24 \mathrm{~h}\end{array}$ & $\begin{array}{l}\text { Decreased mortality } \\
\text { (in-hospital mortality, } \\
\text { primary outcome) }\end{array}$ \\
\hline Comerota, 1993 & Vascular, 134 & $\begin{array}{l}\text { One of three doses of urokinase }(125,000,250,000 \text {, } \\
\text { or } 500,000) \text { infused into the distal circulation } \\
\text { before lower extremity bypass for chronic } \\
\text { limb ischemia } \\
\text { No treatment }\end{array}$ & $\begin{array}{l}\text { Intraoperative } \\
\text { Once }\end{array}$ & $\begin{array}{l}\text { Increased mortality } \\
\text { (death } \\
\text { at NR, secondary } \\
\text { outcome) }\end{array}$ \\
\hline Devereaux, 2008 & Non-cardiac, 8351 & $\begin{array}{l}\text { Extended-release metoprolol } 2-4 \mathrm{~h} \text { before } \\
\text { surgery and continued for } 30 \text { days } \\
\text { Placebo }\end{array}$ & $\begin{array}{l}\text { Preoperative, } \\
\text { postoperative } \\
\text { Once }\end{array}$ & $\begin{array}{l}\text { Increased mortality } \\
\text { (cardiovascular death, NR, } \\
\text { primary outcome) }\end{array}$ \\
\hline Donato, 2007 & Vascular, 192 & $\begin{array}{l}\text { lloprost (intra-arterial, intraoperative bolus) } \\
\text { of } 3000 \mathrm{ng}, \text { plus intravenous infusion of } \\
0.5-2.0 \mathrm{ng} / \mathrm{kg} / \mathrm{min} \text {. } \\
\text { No treatment }\end{array}$ & $\begin{array}{l}\text { Intraoperative, } \\
\text { postoperative } \\
\text { Every day for } \\
\text { a time period }\end{array}$ & $\begin{array}{l}\text { Decreased mortality } \\
\text { (mortality at } 90 \text { days, } \\
\text { primary outcome) }\end{array}$ \\
\hline Donato, 2006 & Vascular, 300 & $\begin{array}{l}\text { Starting from the first day after surgery, a daily } 6 \text {-h } \\
\text { intravenous infusion of iloprost (or placebo) at doses } \\
\text { recommended for chronic critical limb ischemia was } \\
\text { performed for } 4 \text { to } 7 \text { days ( } 7 \text { days recommended). } \\
\text { No treatment }\end{array}$ & $\begin{array}{l}\text { Intraoperative, } \\
\text { postoperative } \\
\text { Every day for } \\
\text { a time period }\end{array}$ & $\begin{array}{l}\text { Decreased mortality } \\
\text { (mortality at } 90 \text { days, } \\
\text { primary outcome) }\end{array}$ \\
\hline Fergusson, 2008 & Cardiac, 2331 & $\begin{array}{l}\text { Aprotinin: test dose of } 40,000 \mathrm{KIU} \text { administered } \\
\text { during a } 10 \text {-min period after insertion of central } \\
\text { venous line and induction of anesthesia. } \\
\text { If no anaphylactic reaction remained for loading } \\
\text { dose ( } 1.96 \text { million KIU) given followed by } \\
\text { maintenance infusion of 500,000 KIU/h } \\
\text { and maintained during surgery. } \\
\text { Aminocaproic acid or tranexamic acid }\end{array}$ & $\begin{array}{l}\text { Intraoperative } \\
\text { During most of the } \\
\text { intraoperative period }\end{array}$ & $\begin{array}{l}\text { Increased mortality } \\
\text { (death } \\
\text { from all causes at } 30 \\
\text { days, } \\
\text { secondary outcome) }\end{array}$ \\
\hline $\begin{array}{l}\text { Giakoumidakis, } \\
2013\end{array}$ & Cardiac, 200 & $\begin{array}{l}\text { Group } 1 \text { received aspirin preoperatively while } \\
\text { in group 2, aspirin was stopped at least } 7 \text { days } \\
\text { before CABG. } \\
\text { No treatment }\end{array}$ & $\begin{array}{l}\text { Preoperative } \\
\text { Once }\end{array}$ & $\begin{array}{l}\text { Decreased mortality } \\
\text { (in-hospital mortality, } \\
\text { primary } \\
\text { outcome) }\end{array}$ \\
\hline Hase, 2013 & Cardiac, 350 & $\begin{array}{l}\text { Bolus of sodium bicarbonate }(0.5 \mathrm{mmol} / \mathrm{kg} \text { in } 250 \mathrm{~mL} \\
\text { over } 1 \mathrm{~h}) \text { at induction followed by an infusion over } \\
\text { the next } 23 \mathrm{~h}(0.2 \mathrm{mmol} / \mathrm{kg} / \mathrm{h} \text { in } 1000 \mathrm{~mL}) \text {. }\end{array}$ & $\begin{array}{l}\text { Intraoperative, } \\
\text { postoperative } \\
24 \mathrm{~h}\end{array}$ & $\begin{array}{l}\text { Increased mortality } \\
\text { (death in-hospital, } \\
\text { secondary } \\
\text { outcome) } \\
\text { ND (death at } 90 \text { days, } \\
\text { secondary outcome) }\end{array}$ \\
\hline Herr, 2000 & NR, 113 & Propofol or propofol plus EDTA & $\begin{array}{l}\text { Intraoperative } \\
\text { Once }\end{array}$ & $\begin{array}{l}\text { Increased mortality } \\
\text { (7-day mortality, } \\
\text { primary outcome) }\end{array}$ \\
\hline Iliuta, 2009 & Cardiac, 1352 & $\begin{array}{l}\text { Group A: patients with betaxolol postoperative } \\
20 \text { mg once daily } \\
\text { Group B: patients with metoprolol postoperative } \\
200 \text { mg in two equal doses daily }\end{array}$ & $\begin{array}{l}\text { Preoperative, } \\
\text { intraoperative } \\
\text { postoperative, after } \\
\text { discharge from hospital } \\
\text { Every day for a time } \\
\text { period }\end{array}$ & $\begin{array}{l}\text { Decreased mortality } \\
\text { (30-day mortality, } \\
\text { primary outcome) }\end{array}$ \\
\hline |lliuta, 2003 & Cardiac, 400 & $\begin{array}{l}\text { Patients received nadroparin } 85 \mathrm{U} / \mathrm{kg} \mathrm{SC} \text { q12h. } \\
\text { Usual care: patients received unfractionated } \\
\text { heparin IV to maintain APTT at } 2.5 \text { the }\end{array}$ & $\begin{array}{l}\text { Postoperative } \\
\text { Every day for } \\
\text { a time period }\end{array}$ & $\begin{array}{l}\text { Decreased mortality } \\
\text { (30-day mortality, } \\
\text { primary outcome) }\end{array}$ \\
\hline
\end{tabular}


Table 3 Summary of mortality outcome for pharmacotherapy interventions for a significant difference in mortality (Continued)

\begin{tabular}{|c|c|c|}
\hline First author, year & $\begin{array}{l}\text { Type of surgery, } \\
\text { no. of participants }\end{array}$ & Intervention/comparison details \\
\hline Kirdemir, 2008 & Cardiac, 200 & $\begin{array}{l}\text { Continuous insulin infusion titrated per protocol } \\
\text { in the perioperative period (Portland protocol) } \\
\text { to maintain blood glucose between } 100 \text { and } 150 \mathrm{mg} / \mathrm{d} \\
\text { Subcutaneous insulin was injected every } 4 \mathrm{~h} \text { in a } \\
\text { directed attempt to maintain blood glucose } \\
\text { levels below } 200 \mathrm{mg} / \mathrm{dL} \text {. }\end{array}$ \\
\hline $\begin{array}{l}\text { Krestchmer, } \\
1989\end{array}$ & Vascular, 252 & $\begin{array}{l}\text { ASA ( } 1-1.5 \mathrm{~g} \text { daily) } \\
\text { No treatment }\end{array}$ \\
\hline
\end{tabular}

Levin, 2012 Cardiac, 93

Levin, 2008 Cardiac, 252

Mentzer, 2008 Cardiac, 5761

Norman, 2009 Thoracic, 16

Poldermans, Vascular, 112 1999*

Reyad, 2013 General, 60

Turpie, 2007 General, 467

Wallace, 2004

General, 190

Wilson, 1999 General, 138
Preoperative loading dose of levosimendan $(10 \mu \mathrm{g} / \mathrm{kg}$ over $60 \mathrm{~min})$ followed by a continuous $23 \mathrm{~h}$ infusion of $0.1 \mathrm{\mu g} / \mathrm{kg} / \mathrm{min}$ No treatment

Preoperative loading dose of levosimendan (10 $\mathrm{\mu g} / \mathrm{kg}$ over $60 \mathrm{~min}$ ) followed by a continuous $23 \mathrm{~h}$ infusion of $0.1 \mu \mathrm{g} / \mathrm{kg} / \mathrm{min}$ No treatment

Intravenous cariporide (180 mg in a 1-h preoperative loading dose, then $40 \mathrm{mg} / \mathrm{h}$ over $24 \mathrm{~h}$ and $20 \mathrm{mg} / \mathrm{h}$ over the subsequent $24 \mathrm{~h}$ ). No treatment

Aprotinin (IV bonus of 2 million KIU followed by a 0.5 million KIU per but infusion). No treatment

Beta-blockade with bisoprolol Usual care with no perioperative blockade

Dobutamine at either $3 \mathrm{mcg} / \mathrm{kg} / \mathrm{min}$ or $5 \mathrm{mcg} / \mathrm{kg} / \mathrm{min}$. No treatment

Injections of fondaparinux $2.5 \mathrm{mg}$ (fondaparinux sodium, Arixtra, NC, USA). No treatment

\section{$0.2 \mathrm{mg}$ oral tablet of clonidine}

(Catapres; Boehringer Ingelheim, Ridgefield, CT), a $7.0-\mathrm{cm}^{2}$ transdermal patch of clonidine (Catapres-TTS-2; Boehringer Ingelheim), providing continuous systemic delivery of $0.2 \mathrm{mg} / \mathrm{day}$, and an oral loading dose of clonidine, 0.2-mg tablet (Catapres).

No treatment

$1 \mathrm{~L}$ of Hartmann's solution during line insertion. Human albumin solution $4.5 \%$ was then infused until a pulmonary artery occlusion pressure of $12 \mathrm{mmHg}$ was achieved. If hemoglobin concentration was $<110 \mathrm{~g} / \mathrm{L}$ red blood cells were transfused instead of the albumin solution. If oxygen saturation was $<94 \%$, supplemental GlaxoSmithKline, Research Triangle Park,

Perioperative phase, Impact on mortality*

duration of intervention (outcome definition, timing)

$\begin{array}{ll}\text { Intraoperative, } & \begin{array}{l}\text { Decreased mortality } \\ \text { postoperative }\end{array} \\ \text { Immediately } & \text { secondary outcome) }\end{array}$

preoperatively

until postop day 3

Preoperative, postoperative, after discharge from hospital

Every day for

a time period

Preoperative

Every day for a time period

Preoperative, intraoperative Every day for a time period

Preoperative

Intraoperative

Once

Preoperative, intraoperative postoperative Until surgery

Intraoperative During most of the intraoperative phase

Postoperative

Every day for a time period: daily for 5-9 days

Preoperative, intraoperative, postoperative Every day for a time period: 4 days

Preoperative, intraoperative, postoperative Minimum of $4 \mathrm{~h}$ before surgery, continued for at least $12 \mathrm{~h}$ afterwards.
Decreased mortality (probability of survival at 6 years, primary outcome)

Decreased mortality (30-day mortality, primary outcome)

Decreased mortality (30-day mortality, primary outcome)

Increased mortality (all-cause mortality at day 5 , secondary outcome) Increased mortality (all-cause mortality at day 30 , secondary outcome) ND (all-cause mortality at 6 months, secondary outcome)

Decreased mortality (survival at NR, secondary outcome)

Decreased mortality (perioperative death, primary outcome)

Decreased mortality (death in-hospital, secondary outcome)

Decreased mortality (death at 30 days, secondary outcome)

Decreased mortality (30-day mortality, NR) Decreased mortality (2-year mortality, NR)

Decreased mortality (in-hospital mortality, primary outcome) 
Table 3 Summary of mortality outcome for pharmacotherapy interventions for a significant difference in mortality (Continued)

\begin{tabular}{ccc}
\hline First author, year $\begin{array}{l}\text { Type of surgery, } \\
\text { no. of participants }\end{array}$ & $\begin{array}{l}\text { Perioperative phase, } \\
\text { duration of intervention }\end{array}$ & (outcome definition, \\
& timing)
\end{tabular}

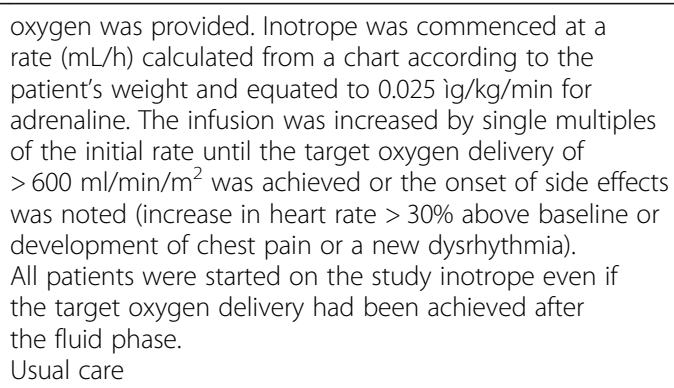

Anesthesia-related intervention refers to the interventions provided in the perioperative period that was or could be performed, organized, or initiated by a healthcare professional with specific training in anesthesia

$N D$ no significant change, $N R$ not reported

*This study was part of an investigation of academic integrity. The investigating committee was unable to confirm or deny any doubts surrounding the conduct of the study, and it thus not retracted from the journal where it was published. We therefore did not exclude the study from our scoping review

generalizability of the effect of specific types of pharmacotherapy and dosages to perioperative survival in a broader variety of surgical populations.

The institutional context where these interventions are applied may also require more systematic reporting and further investigations. For example, McIsaac et al. recently demonstrated that the "hip fracture surgery patients at hospitals that use more than 20 to $25 \%$ neuraxial anesthesia have improved survival independent of patient-level anesthesia type and other confounders" [51]. Although broad categorizations of interventions are a useful starting point, one may hypothesize that other traditionally overlooked variables may need to be accounted for to better understand the effect of an intervention. For example, variables such as the type of institution, the implementation process of implementation, or local organization of care may help understanding the part of the effect of an intervention.
In addition to pharmacotherapy, other intervention themes were found promising to reduce mortality: ventilation, transfusion, nutrition, glucose control, dialysis, and medical device. Though these themes had a limited number of studies demonstrating a decrease in mortality, they may be encouraging to investigate further. For example, systematic reviews may explore nutritional or ventilation-related interventions to precisely identify promising practices within these themes that improve morbidity in addition to mortality. This is particularly important given the perceived importance of many of these interventions to practicing clinicians as determined in the Landoni et al. consensus study [50]. Clearly establishing the benefits of these types of interventions is important to facilitate their widespread uptake by clinicians if supported by the available evidence.

Though many promising types of interventions were identified, it is noteworthy that none of the included

Table 4 Summary of mortality outcome for nutritional interventions for significant difference in mortality

\begin{tabular}{|c|c|c|c|c|}
\hline $\begin{array}{l}\text { First } \\
\text { author, } \\
\text { year }\end{array}$ & $\begin{array}{l}\text { Type of surgery, no. } \\
\text { of participants }\end{array}$ & Intervention/comparison details & $\begin{array}{l}\text { Perioperative phase, } \\
\text { duration of intervention }\end{array}$ & $\begin{array}{l}\text { Impact on mortality* (outcome } \\
\text { definition, timing) }\end{array}$ \\
\hline $\begin{array}{l}\text { Cooper, } \\
2006\end{array}$ & $\begin{array}{l}\text { Thoracic-oncological, } \\
27\end{array}$ & $\begin{array}{l}\text { Total parenteral nutrition } \\
\text { Usual care: maintaining patients } \\
\text { NPO until postop day } 4, \\
\text { then initiating an oral diet }\end{array}$ & $\begin{array}{l}\text { Preoperative, } \\
\text { postoperative } \\
\text { Every day for } \\
\text { a time period }\end{array}$ & $\begin{array}{l}\text { Increased mortality (90-day } \\
\text { mortality, primary outcome) } \\
\text { ND (1-year mortality, primary } \\
\text { outcome) }\end{array}$ \\
\hline $\begin{array}{l}\text { Duncan, } \\
2005\end{array}$ & Orthopedic, 302 & $\begin{array}{l}\text { Feeding support by dietetic assistants } \\
\text { Usual care: traditional nurse- and } \\
\text { dietitian-led nutrition and feeding } \\
\text { postop }\end{array}$ & $\begin{array}{l}\text { Postoperative } \\
\text { Every day for a time } \\
\text { period until discharge }\end{array}$ & $\begin{array}{l}\text { Increased mortality (death in } \\
\text { trauma unit, primary outcome) } \\
\text { Decreased mortality (death at } \\
4 \text { months, secondary outcome) } \\
\text { ND (death in-hospital, secondary } \\
\text { outcome) }\end{array}$ \\
\hline Wu, 2006 & Colorectal, 468 & $\begin{array}{l}7 \text { days preop and } 7 \text { days postop either } \\
\text { parenteral or enteral nutrition } \\
\text { Usual care: usual hospital diet preop } \\
\text { and then hypocaloric parenteral solution postop }\end{array}$ & $\begin{array}{l}\text { Preoperative, postoperative } \\
\text { Every day for a time period }\end{array}$ & $\begin{array}{l}\text { Decreased mortality } \\
\text { (in-hospital mortality, NR) }\end{array}$ \\
\hline
\end{tabular}


Table 5 Summary of mortality outcome for transfusion interventions for a significant difference in mortality

\begin{tabular}{|c|c|c|c|c|}
\hline $\begin{array}{l}\text { First author, } \\
\text { year }\end{array}$ & $\begin{array}{l}\text { Type of surgery, } \\
\text { no. of participants }\end{array}$ & Intervention/comparison details & $\begin{array}{l}\text { Perioperative phase, } \\
\text { duration of intervention }\end{array}$ & $\begin{array}{l}\text { Impact on mortality* } \\
\text { (outcome definition, timing) }\end{array}$ \\
\hline Bilgin, 2004 & Cardiac, 474 & $\begin{array}{l}\text { Leuko-depleted red blood cell transfusion. } \\
\text { Platelet concentrates were prepared from } \\
\text { pooled buffy coats and were all } \\
\text { leukocyte-depleted by filtration } \\
\left(<1 \times 10^{6} \text { leukocytes per product }\right) \\
\text { before storage. } \\
\text { Standard buffy coat-depleted } \\
\text { packaged cells. }\end{array}$ & $\begin{array}{l}\text { Intraoperative } \\
\text { During most of the } \\
\text { intraoperative phase }\end{array}$ & $\begin{array}{l}\text { Decreased mortality } \\
\text { (in-hospital, } \\
\text { secondary outcome) }\end{array}$ \\
\hline Foss, 2009 & Orthopedic, 107 & $\begin{array}{l}\text { A hemoglobin threshold of } 10.0 \mathrm{~g} / \mathrm{dL} \\
\text { (liberal) versus } 8.0 \mathrm{~g} / \mathrm{dL} \text { (restrictive) } \\
\text { in the entire perioperative period } \\
\text { Receive transfusion at a hemoglobin } \\
\text { threshold of } 8.0 \mathrm{~g} / \mathrm{dL} \text { (restrictive) } \\
\text { in the entire perioperative period. }\end{array}$ & $\begin{array}{l}\text { Preoperative, Intraoperative, } \\
\text { postoperative } \\
\text { During most of the } \\
\text { intraoperative phase }\end{array}$ & $\begin{array}{l}\text { Decreased mortality (30-day } \\
\text { mortality, secondary outcome) }\end{array}$ \\
\hline $\begin{array}{l}\text { Kosmadakis, } \\
2003\end{array}$ & Colorectal, 63 & $\begin{array}{l}\text { The intervention involved administration } \\
\text { of subcutaneous erythropoietin (r-HuEPO } \\
\text { at } 300 \mathrm{IU} / \mathrm{kg} \text { ) plus IV iron ( } 100 \mathrm{mg} \text { ) for } \\
7 \text { days preop, and } 7 \text { days postop surgery } \\
\text { for gastrointestinal malignancies. } \\
\text { Received placebo medication } \\
\text { subcutaneously and } 100 \mathrm{mg} \\
\text { iron intravenously each day. }\end{array}$ & $\begin{array}{l}\text { Preoperative, postoperative } \\
\text { Every day for a time period: } \\
\text { "erythropoietin or placebo } \\
\text { applications were given } \\
\text { for } 14 \text { days perioperatively, } \\
\text { starting } 7 \text { days before } \\
\text { the operation." }\end{array}$ & Decreased mortality (1-year survival, NR \\
\hline $\begin{array}{l}\text { Van de } \\
\text { Watering, } \\
1998\end{array}$ & Cardiac, 914 & $\begin{array}{l}\text { One of the following three trial arms: "( } 1 \text { ) } \\
\text { the PC trial arm, in which when } \\
\text { transfusion was indicated, standard } \\
\text { packed cells (PC) without buffy coat were } \\
\text { transfused; (2) the prestorage filtration FF } \\
\text { trial arm, in which when transfusion was } \\
\text { indicated, freshly filtered (i.e., <24 h after } \\
\text { donation) units were transfused; and (3) } \\
\text { the poststorage filtration SF trial arm, ill } \\
\text { which when transfusion was indicated, 6- } \\
\text { to } 20 \text {-day stored packed cells without } \\
\text { buffy coat were filtered shortly before } \\
\text { transfusion." }\end{array}$ & $\begin{array}{l}\text { Intraoperative } \\
\text { During most of } \\
\text { the intraoperative phase }\end{array}$ & $\begin{array}{l}\text { Decreased mortality } \\
\text { (in-hospital, NR) }\end{array}$ \\
\hline
\end{tabular}

Anesthesia-related intervention refers to interventions provided in the perioperative period that was or could be performed, organized, or initiated by a healthcare professional with specific training in anesthesia

$N D$ no significant change, $N R$ not reported

RCTs investigated the impact of "non-traditional interventions" such as team training [52] or hypnosedation [53] on perioperative mortality. These types of interventions may require more exploratory work in perioperative medicine and could be used in future knowledge translation initiatives if found to be effective. It is also interesting to note that the vast majority of included studies investigated a single type of intervention. Given the low mortality rate in perioperative medicine, at least in high-income Western countries, it may be useful in the future to combine themes and interventions in bundle or multifaceted interventions to further decrease mortality with adequate power.

An additional target for improvement in perioperative research highlighted by our scoping review is standardization in outcome measurement. Even with mortality as an outcome, we observed variability in the definition used based on the time window, cause of death, or mode of data collection considered. A common, well-accepted definition of outcomes may facilitate interpretation of future studies. To this end, several recent initiatives have been launched to tackle the issue of core outcome selection and definition [54-57]. Mortality has been identified as a core outcome measure within these initiatives, but as this scoping review demonstrates, the perioperative and anesthesia-research community must still determine the most effective way to measure and report it. This could have significant implications for interpretations of intervention effectiveness.

Our scoping review should be interpreted in light of several limitations. Firstly, the majority of published studies were not sufficiently powered to observe a statistical impact on mortality; the sample sizes were small, on average. Perioperative mortality is increasingly rare and is estimated at only 0.1 to $0.2 \%$ of healthy elective patients when measuring in-hospital mortality [58] and around a 4\% 1-year mortality rate after major non-cardiac surgery [59]. While only 39 included studies found a significant impact of the intervention on mortality, this may be due to the fact that most studies 
Table 6 Summary of mortality outcome for ventilation interventions for a significant difference in mortality

\begin{tabular}{|c|c|c|c|c|}
\hline $\begin{array}{l}\text { First author, } \\
\text { year }\end{array}$ & $\begin{array}{l}\text { Type of surgery, } \\
\text { no. of participants }\end{array}$ & Intervention/comparison details & $\begin{array}{l}\text { Perioperative phase, } \\
\text { duration of intervention }\end{array}$ & $\begin{array}{l}\text { Impact on mortality* } \\
\text { (outcome definition, timing) }\end{array}$ \\
\hline $\begin{array}{l}\text { Antonelli, } \\
2000\end{array}$ & $\begin{array}{l}\text { General or } \\
\text { Thoracic, } 40\end{array}$ & $\begin{array}{l}\text { Non-invasive ventilation: "...the ventilator } \\
\text { was connected with conventional tubing } \\
\text { to a clear, full face mask with an inflatable } \\
\text { soft cushion seal and a disposable foam } \\
\text { spacer to reduce dead space. After the } \\
\text { mask was secured, pressure support was } \\
\text { increased to obtain an exhaled tidal } \\
\text { volume of } 8 \text { to } 10 \mathrm{~mL} / \mathrm{kg} \text {, a respiratory } \\
\text { rate of fewer than } 25 \text { per minute, the } \\
\text { disappearance of accessory muscle } \\
\text { activity (as evaluated by palpating the } \\
\text { sternocleidomastoid muscle), and patient } \\
\text { comfort. Positive end-expiratory pressure } \\
\text { was increased in increments of } 2 \text { to } \\
3 \mathrm{~cm} \mathrm{H} 2 \mathrm{O} \text { repeatedly up to } 10 \mathrm{~cm} \mathrm{H} 2 \mathrm{O}\end{array}$ & $\begin{array}{l}\text { Postoperative } \\
\text { "During the first } 24 \text { h, ventilation } \\
\text { was continuously maintained until } \\
\text { oxygenation and clinical status } \\
\text { improved. Subsequently, each patient } \\
\text { was evaluated daily while breathing } \\
\text { supplemental oxygen without ventilatory } \\
\text { support for } 15 \text { min. Non-invasive } \\
\text { ventilation was reduced progressively } \\
\text { in accordance with the degree of clinical } \\
\text { improvement and was discontinued } \\
\text { if the patient maintained a respiratory } \\
\mathrm{rate} \text { lower than } 30 \text { per minute and a } \\
\mathrm{PaO}_{2} \text { greater than } 75 \text { mmHg with a } \\
\mathrm{FiO}_{2} \text { of } 0.5 \text { without ventilatory support." }\end{array}$ & $\begin{array}{l}\text { Decreased mortality } \\
\text { (rate of fatal complications, } \\
\text { in-hospital, primary } \\
\text { outcome) }\end{array}$ \\
\hline
\end{tabular}

\section{Auriant, 2001 Thoracic, 48} surgery, 37

Meyoff, 2012 General, 1382

Zhu, $2013 \quad$ Cardiac, 95 vascular surgery at $520-600 \mathrm{ml} / \mathrm{min} / \mathrm{m}^{2}$ randomization and for $2 \mathrm{~h}$ after surgery
Lobo, 2000 Major oncological Increased oxygen levels to $>600 \mathrm{ml} / \mathrm{min} / \mathrm{m}^{2}$

less."

Standard treatment with supplemental oxygen administration

NPW: "Ventilation was provided via a cushion bridge nasal mask (Profil lite; Respironics.Inc., Murrysville, PA). NPPV was provided with the BiPAP S/T-D Ventilatory Support System (Bipap Vision; Respironics, Inc.). Pressure support was increased to achieve an exhaled tidal volume of 8 to $10 \mathrm{~mL} / \mathrm{kg}$ and a respiratory rate of less than 25 breaths per minute. The $\mathrm{FiO}_{2}$ was adjusted to obtain a percutaneous oxygen saturation above 90\%."

Standard treatment: "All patients received oxygen supplementation to achieve an $\mathrm{SaO}_{2}$ above 90\%, bronchodilators (aerosolized albuterol), patient-controlled analgesia (PCA) (bolus dose $=1 \mathrm{mg}$ morphine, lockout interval $7 \mathrm{~min}$, maximum hourly dose $=7 \mathrm{mg}$ ), and chest physiotherapy." in patients post-major oncological or Control group maintained oxygen delivery

After tracheal intubation, patients were given an $\mathrm{FiO}_{2}$ of 0.80 or 0.30 according to the

Usual care: receive $30 \%$ oxygen during

Non-invasive positive pressure ventilation (NPPV). "NPPV therapy was administered using the bilevel positive airways pressure (BiPAP) $\mathrm{S} / \mathrm{T}$ mode (Resmed, VPAP III, Australia) via a properly fitted face mask (ZS-MZ-, Zhongshan Technique Development Co., Shanghai)... The initial inspiratory pressure (IPAP) was set at $12 \mathrm{cmH}_{2} \mathrm{O}$.. According to clinical efficacy and patient tolerance, we raised the IPAP and (or) EPAP by $2-3 \mathrm{CmH}_{2} \mathrm{O}$ every 5 to $10 \mathrm{~min}$...All patients continued to receive NPPV except for coughing, eating, and talking until their condition was improved. Then NPPV was administered intermittently and the IPAP/EPAP was decreased gradually."

"Standard medical care and oxygen therapy as needed."
Postoperative

"The duration of ventilation was standardized according to Wysocki and coworkers."

Intraoperative, postoperative For the first $24 \mathrm{~h}$ of postop ICU admission

Intraoperative, postoperative During most of the intraoperative phase

Postoperative

Until the condition improved.
Decreased mortality (inhospital and 120 days, secondary outcomes)
ND (28-day mortality, primary outcome)

Decreased mortality (60-day mortality, primary outcome)

Increased mortality (allcause mortality at 2 years, primary outcome)

Decreased mortality (inhospital mortality, primary)

Anesthesia-related intervention refers to interventions provided in the perioperative period that was or could be performed, organized, or initiated by a healthcare professional with specific training in anesthesia

$N D$ no significant change, $N R$ not reported 
Table 7 Summary of mortality outcome for device, dialysis, and glucose control interventions for a significant difference in mortality

\begin{tabular}{|c|c|c|c|c|c|}
\hline $\begin{array}{l}\text { First } \\
\text { author, year }\end{array}$ & $\begin{array}{l}\text { Type of } \\
\text { surgery }\end{array}$ & $\begin{array}{l}\text { Anesthesia-related } \\
\text { intervention theme }\end{array}$ & Intervention/ comparison details & $\begin{array}{l}\text { Perioperative phase, } \\
\text { duration of intervention }\end{array}$ & $\begin{array}{l}\text { Impact on mortality* } \\
\text { (outcome definition, timing) }\end{array}$ \\
\hline Durmaz, 2003 & Cardiac, 44 & Dialysis & $\begin{array}{l}\text { Prophylactic preoperative } \\
\text { hemodialysis for patients } \\
\text { undergoing CABG surgery with } \\
\text { underlying renal failure. } \\
\text { Usual care: received postoperative } \\
\text { dialysis if there was a } 50 \% \text { increase } \\
\text { in serum creatinine from baseline } \\
\text { or patient exhibited inadequate } \\
\text { urine output less than } 400 \mathrm{~mL} \text { for } \\
24 \mathrm{~h} \text { despite correction of } \\
\text { hemodynamic status and } \\
\text { diuretic therapy. }\end{array}$ & $\begin{array}{l}\text { Preoperative, } \\
\text { postoperative } \\
\text { Every day for } \\
\text { a time period }\end{array}$ & $\begin{array}{l}\text { Decreased mortality } \\
\text { (in-hospital mortality, NR) }\end{array}$ \\
\hline Thielman, 2013 & Cardiac, 329 & Medical device & $\begin{array}{l}\text { Remote ischemic preconditioning } \\
\text { took place after induction of } \\
\text { anesthesia and before skin } \\
\text { incision. Three cycles of } 5 \text { min } \\
\text { ischemia, achieved by inflation of } \\
\text { a blood pressure cuff to } \\
200 \mathrm{mmHg} \text {, followed by } 5 \text { min } \\
\text { reperfusion while the cuff was } \\
\text { deflated were applied to the } \\
\text { upper left arm. } \\
\text { No treatment }\end{array}$ & $\begin{array}{l}\text { Intraoperative } \\
\text { Once }\end{array}$ & $\begin{array}{l}\text { Decreased mortality } \\
\text { (all-cause } 30 \text {-day mortality, } \\
\text { secondary outcome) }\end{array}$ \\
\hline Qiu, 2009 & Cardiac, 221 & Medical Device & $\begin{array}{l}\text { "The IABP catheter used was } 8 \text { F } \\
34 \text { ml balloon Percor STAT-DL } \\
\text { Catheter (Datascope Corp, } \\
\text { Fairfield, NJ) connected to a } \\
\text { Datascope portable computerized } \\
\text { console (Datascope), placed using } \\
\text { percutaneous insertion technique } \\
\text { via the femoral artery." } \\
\text { "Preoperative insertion was } \\
\text { normally performed in the anesthesia } \\
\text { preparation room in the operating } \\
\text { room (OR) prior to induction } \\
\text { of anesthesia." }\end{array}$ & $\begin{array}{l}\text { Intraoperative } \\
\text { During most of the } \\
\text { intraoperative period }\end{array}$ & $\begin{array}{l}\text { Decreased mortality } \\
\text { (in-hospital, NR) }\end{array}$ \\
\hline $\begin{array}{l}\text { van den Berghe, } \\
2001\end{array}$ & $N R, 1548$ & Glucose control & $\begin{array}{l}\text { Intensive insulin therapy (target } \\
\text { blood glucose of } 80-110 \mathrm{mg} / \mathrm{dL} \text { ) in } \\
\text { mechanically ventilated ICU patients } \\
\text { Usual care: a continuous infusion of } \\
\text { insulin ( } 50 \mathrm{IU} \text { in } 50 \mathrm{~mL} 0.9 \% \mathrm{NaCl} \text { ) } \\
\text { was started only if the blood glucose } \\
\text { level exceeded } 215 \mathrm{mg} / \mathrm{dL} \text {, with the } \\
\text { infusion adjusted to maintain the } \\
\text { level between } 180 \text { and } 200 \mathrm{mg} / \mathrm{dL} \text {. }\end{array}$ & $\begin{array}{l}\text { Postoperative } \\
\text { In the intervention group, } \\
\text { the intensive treatment } \\
\text { approach was followed } \\
\text { until the patient was } \\
\text { discharged from the } \\
\text { intensive care unit, at } \\
\text { which point the } \\
\text { conventional approach } \\
\text { was adopted. }\end{array}$ & $\begin{array}{l}\text { Decreased mortality } \\
\text { (death during intensive } \\
\text { care, primary outcome) } \\
\text { Decreased mortality } \\
\text { (in-hospital mortality, } \\
\text { secondary outcome) }\end{array}$ \\
\hline
\end{tabular}

Anesthesia-related intervention refers to interventions provided in the perioperative period that was or could be performed, organized, or initiated by a healthcare professional with specific training in anesthesia

$N D$ no significant change, NR not reported

included mortality as a non-primary outcome. The lack of power to assess mortality may have resulted in a type II error (i.e., failure to observe a difference where one exists). However, this scoping review should be considered as an initial step to guide the field of perioperative research. Secondly, for feasibility reasons, we elected to include only RCTs that considered mortality outcome. There are of course many other meaningful outcome measures that are clinically relevant to surgical patients. However, mortality may be appropriate as a starting point.
Thirdly, although we followed rigorous and standardized methods, it is likely that relevant studies were missed. Due to the process of conducting systematic and scoping reviews through a literature search strategy and screening, studies could not be included if neither the title nor the abstract mentioned any term related to mortality. For example, some studies mention somewhere in the results section an absence of deaths during the study, although mortality was not reported in the title or abstract, or included in the methods [60]. Nevertheless, when the title, abstract, and/or keywords of a 
study do not accurately reflect all outcomes examined, this presents a significant challenge for literature analysis in anesthesia and increases the potential for missing studies. It is also possible that some articles may not have had appropriate perioperative subject headings in MEDLINE or perioperative keywords included in the abstract, which would have resulted in them not being retrieved by our search. Future work in anesthesia should aim to accurately index all RCTs. A search filter developed specifically for anesthesia would also be of value and should consider subject headings for the perioperative period that reference preoperative, intraoperative, and postoperative time frames. To mitigate the current problem of standardized literature searching in anesthesia, we used artificial intelligence and expert review.

Finally, there are limitations to the depth of analysis for a scoping review. Therefore, as per scoping review methods, the intention is to map out a field of evidence rather than to thoroughly analyze each trial. The identification of gaps in the existing literature should be cautiously interpreted since the quality of evidence is not typically assessed during scoping reviews [23]. These last two limitations may lead to misleading conclusions about the nature and extent of the gaps in the present research. However, the information reported in this scoping review provides a broad overview about the nature and distribution of studies involved with perioperative anesthesia interventions. Future steps could include systematic reviews on individual themes to provide more specific insight into these questions with a narrower focus.

Future systematic reviews conducted to formally synthesize specific intervention themes identified by this scoping review should examine clinical, methodological, and statistical heterogeneity and conduct meta-analyses as appropriate.

\section{Conclusion}

This scoping review described intervention themes based on existing anesthesia research. As a result, it has identified areas requiring further systematic investigation given their potential value for reducing patient mortality as well as areas where continued investment may not be cost-effective based on limited or no evidence for enhancing patient outcome. Accordingly, this scoping review provides a starting point for future knowledge translation designed to optimize anesthesia practice.

\section{Additional files}

Additional file 1: Search strategies. (DOCX $14 \mathrm{~kb}$ )

Additional file 2: Intervention themes and definitions. (DOCX $15 \mathrm{~kb}$ )
Additional file 3: Study and population characteristics. (DOCX $127 \mathrm{~kb}$ )

Additional file 4: PRISMA Checklist. (PPT $2341 \mathrm{~kb}$ )

\section{Abbreviations}

Al: Artificial Intelligence; KT: Knowledge translation; ND: No significant change; NR: Not reported; PRESS: Peer Review of Electronic Search Strategies; $\mathrm{RCT}$ : Randomized controlled trial

\section{Acknowledgements}

The authors thank Lee-Anne Ufholz, information specialist, for her help with the literature search.

\section{Funding}

This research was funded by a University of Ottawa Anesthesia Research operating grant. Drs. Boet, Lalu, and Mclsaac were supported by the Ottawa Hospital Anesthesia Alternate Funds Association, and Dr. Boet was also supported by the Canadian Anesthesia Research Foundation through the Canadian Anesthesiologists' Society (CAS) Career Scientist Award in Anesthesia. DSR licenses were funded by the Department of Anesthesiology and Pain Medicine of The Ottawa Hospital.

\section{Availability of data and materials}

The datasets generated and/or analyzed during the current study are available from the corresponding author on reasonable request.

\section{Authors' contributions}

All authors have a substantial contribution to the conception and design, acquisition of data, or analysis and interpretation of data; drafted the article and revised it critically for important intellectual content; approved the final version to be published; and agreed to be accountable for all aspects of the work thereby ensuring that questions related to the accuracy or integrity of any part of the work are appropriately investigated and resolved.

Ethics approval and consent to participate

Not applicable.

Consent for publication

Not applicable.

Competing interests

The authors declare that they have no competing interests.

\section{Publisher's Note}

Springer Nature remains neutral with regard to jurisdictional claims in published maps and institutional affiliations.

\section{Author details}

${ }^{1}$ Department of Anesthesiology and Pain Medicine, The Ottawa Hospital, University of Ottawa, General Campus, 501 Smyth Rd, Critical Care Wing 1401, Ottawa, Ontario K1H 8L6, Canada. ${ }^{2}$ Clinical Epidemiology Program, Ottawa Hospital Research Institute, Ottawa, Canada. ${ }^{3}$ Family Medicine, McGill University, Montreal, Canada. ${ }^{4}$ Knowledge Synthesis Group, Clinical Epidemiology Program, Ottawa Hospital Research Institute, Ottawa, Canada. ${ }^{5}$ Department of Anesthesia, University of Toronto, Toronto, Canada. ${ }^{6}$ Faculty of Medicine, University of Ottawa, Ottawa, Canada. ${ }^{7}$ University of Ottawa, Ottawa, Canada. ${ }^{8}$ Department of Anesthesiology, McGill University, Montreal, Quebec, Canada. ${ }^{9}$ Department of Anesthesia, University of Utah, Salt Lake City, UT 84132, USA. ${ }^{10}$ Department of Family Medicine, Montfort Hospital, University of Ottawa, Ottawa, Canada. ${ }^{11}$ Department of Anesthesiology and Pain Medicine, The Ottawa Hospital, Ottawa, Canada. ${ }^{12}$ Clinical Epidemiology and Regenerative Medicine Programs, Ottawa Hospital Research Institute, Ottawa, Canada. ${ }^{13}$ School of Epidemiology and Public Health, University of Ottawa, Ottawa, Ontario K1G 5Z3, Canada. 
Received: 14 June 2018 Accepted: 30 October 2018 Published online: 30 November 2018

\section{References}

1. Weiser TG, Regenbogen SE, Thompson KD, et al. An estimation of the global volume of surgery: a modelling strategy based on available data. Lancet. 2008;372(9633):139-44. https://doi.org/10.1016/S01406736(08)60878-850140-6736(08)60878-8 [pii].

2. Meakins JL, Giobbie-Hurder A, Jonasson O, et al. Evidence-based surgery. Surg Clin North Am. 2006;86(1):1-16, vii. https://doi.org/10.1016/j.suc.2005.10.004

3. Hackbarth $A D$, Hackbarth AD. Eliminating waste in US health care. JAMA. 2012;307(14):1513. https://doi.org/10.1001/jama.2012.362.

4. Beaupre LA, Jones CA, Saunders LD, Johnston DWC, Buckingham J, Majumdar SR. Best practices for elderly hip fracture patients. J Gen Intern Med. 2005;20(11):1019-25. https://doi.org/10.1111/j.1525-1497.2005.00219.x.

5. Mazzocco K, Petitti DB, Fong KT, et al. Surgical team behaviors and patient outcomes. Am J Surg. 2009;197(5):678-85. https://doi.org/10.1016/j.amjsurg. 2008.03.002

6. Pronovost PJ, Rinke ML, Emery K, Dennison C, Blackledge C, Berenholtz SM Interventions to reduce mortality among patients treated in intensive care units. J Crit Care. 2004;19(3):158-64. https://doi.org/10.1016/j.jcrc.2004.07.003.

7. Shehata N, Wilson K, Mazer CD, et al. The proportion of variation in perioperative transfusion decisions in Canada attributable to the hospital. Can J Anesth Can d'anesthésie. 2007:54(11):902-7. https://doi.org/10.1007/ BF03026794

8. Kalhan R, Mikkelsen M, Dedhiya P, et al. Underuse of lung protective ventilation: analysis of potential factors to explain physician behavior* Crit Care Med. 2006;34(2):300-6. https://doi.org/10.1097/01.CCM.0000198328.83571.4A.

9. Weller JM, Merry AF. I. Best practice and patient safety in anaesthesia. Br J Anaesth. 2013;110(5):671-3. https://doi.org/10.1093/bja/aet011.

10. Kirkland KB, Briggs JP, Trivette SL, Wilkinson WE, Sexton DJ. The impact of surgical-site infections in the 1990s: attributable mortality, excess length of hospitalization, and extra costs. Infect Control Hosp Epidemiol. 1999;20(11): 725-30. https://doi.org/10.1086/501572.

11. Boyce JM, Potter-Bynoe G, Dziobek L. Hospital reimbursement patterns among patients with surgical wound infections following open heart surgery. Infect Control Hosp Epidemiol. 1990;11(2):89-93. https://doi.org/10. 2307/30144267.

12. Asensio Vegas A, Monge Jodra V, Lizán García M, Asensio Vegasi A, Lizan Garcia M. Nosocomial infection in surgery wards: a controlled study of increased duration of hospital stays and direct cost of hospitalization. Source Eur J Epidemiol Eur J Epidemiol Eur J Epidemiol. 1993;9(5):504-10 http://www.jstor.org/stable/3520947. Accessed 25 May 2017.

13. Poulsen KB, Bremmelgaard A, Sorensen Al, Raahave D, Petersen JV. Estimated costs of postoperative wound infections: a case-control study of marginal hospital and social security costs. Epidemiol Infect. 1994;113:28395 https://www-ncbi-nlm-nih-gov.proxy1.lib.uwo.ca/pmc/articles/ PMC2271539/pdf/epidinfect00047-0085.pdf. Accessed 25 May 2017.

14. Kurz A, Sessler DI, Lenhardt R. Perioperative normothermia to reduce the incidence of surgical-wound infection and shorten hospitalization. N Engl J Med. 1996;334(19):1209-16. https://doi.org/10.1056/NEJM199605093341901.

15. Harper CM, Andrzejowski JC, Alexander R. NICE and warm. Br J Anaesth. 2008;101(3):293-5. https://doi.org/10.1093/bja/aen233.

16. Cheng D, Martin J. Evidence-based practice and health technology assessment: a call for anesthesiologists to engage in knowledge translation. Can J Anesth Can d'anesthésie. 2011;58(4):354-63. https://doi.org/10.1007/ s12630-011-9463-0.

17. Graham ID, Logan J, Harrison MB, et al. Lost in knowledge translation: time for a map? J Contin Educ Heal Prof. 2006;26(1):13-24. https://doi.org/10.1002/chp.47.

18. Tricco AC, Cogo E, Ashoor H, et al. Sustainability of knowledge translation interventions in healthcare decision-making: protocol for a scoping review. BMJ Open. 2013;3(5):e002970. https:/doi.org/10.1136/bmjopen-2013-002970.

19. Straus S, Tetroe J, Graham I. Knowledge translation in health care: moving from evidence to practice. London: BMJ Books; 2013.

20. Rodgers A, Walker N, Schug S, et al. Reduction of postoperative mortality and morbidity with epidural or spinal anaesthesia: results from overview of randomised trials. BMJ. 2000;321(7275):1493 http://www.bmj.com.proxy1.lib. uwo.ca/content/321/7275/1493.long. Accessed 25 May 2017.

21. Landoni G, Rodseth RN, Santini F, et al. Randomized evidence for reduction of perioperative mortality. J Cardiothorac Vasc Anesth. 2012;26(5):764-72. https://doi.org/10.1053/j.jvca.2012.04.018.
22. Arksey H, O'Malley L. Scoping studies: towards a methodological framework. Int J Soc Res Methodol. 2005:8(1):19-32. https://doi.org/10.1080/ 1364557032000119616.

23. Armstrong R, Hall BJ, Doyle J, Waters E. "Scoping the scope" of a Cochrane review. J Public Health (Bangkok). 2011;33(1):147-50. https://doi.org/10.1093/ pubmed/fdr015.

24. Rumrill PD, Fitzgerald SM, Merchant WR. Using scoping literature reviews as a means of understanding and interpreting existing literature. Work. 2010; 35(3):399-404. https://doi.org/10.3233/WOR-2010-0998.

25. Brien SE, Lorenzetti DL, Lewis S, Kennedy J, Ghali WA. Overview of a formal scoping review on health system report cards. Implement Sci. 2010;5(1):2. https://doi.org/10.1186/1748-5908-5-2.

26. Tricco AC, Lillie E, Zarin W, et al. PRISMA Extension for Scoping Reviews (PRISMA-SCR): checklist and explanation. Ann Intern Med. 2018;169(7):46773. https://doi.org/10.7326/M18-0850.

27. Levac D, Colquhoun H, O'Brien K. Scoping studies: advancing the methodology. Implement Sci. 2010;5(69):1-9. https://doi.org/10.1111/j.14680009.2005.00403.x

28. Warters R, Szmuk P, Pivalizza E, Gebhard R, Ezri T. Preoperative antibiotic prophylaxis: the role of the anesthesiologist. Anesthesiology. 2003;99(2):5156 http://anesthesiology.pubs.asahq.org/article.aspx?articleid=1943451. Accessed 4 Aug 2017.

29. Healy DA, Clarke Moloney M, McHugh SM, Grace PA, Walsh SR. Remote ischaemic preconditioning as a method for perioperative cardioprotection: concepts, applications and future directions. Int J Surg. 2014;12(10):1093-9. https://doi.org/10.1016/j.jijsu.2014.08.352.

30. Auriant I, Jallot $A$, Hervé $P$, et al. Noninvasive ventilation reduces mortality in acute respiratory failure following lung resection. Am J Respir Crit Care Med. 2001;164(7):1231-5. https://doi.org/10.1164/ajrccm.164.7.2101089.

31. Sampson M, McGowan J, Cogo E, Grimshaw J, Moher D, Lefebvre C. An evidence-based practice guideline for the peer review of electronic search strategies. J Clin Epidemiol. 2009;62(9):944-52. https://doi.org/10.1016/j. jclinepi.2008.10.012.

32. McGowan J, Sampson M, Lefebvre C. An Evidence Based Checklist for the Peer Review of Electronic Search Strategies (PRESS EBC). Evid Based Libr Inf Pract. 2010;5(1):149. https://doi.org/10.18438/B8SG8R.

33. Khangura S, Konnyu K, Cushman R, Grimshaw J, Moher D. Evidence summaries: the evolution of a rapid review approach. Syst Rev Rev. 2012;1: 10. https://doi.org/10.7326/0003-4819-148-10-200805200-00010.

34. Moher D, Squires JE, Kolehmainen N, et al. Preferred Reporting Items for Systematic Reviews and Meta-Analyses: the PRISMA Statement. Ann Intern Med. 2009;151(4):264. https://doi.org/10.7326/0003-4819-151-4200908180-00135.

35. Cooper S, Hulley C, Grimley C, et al. Perioperative peripheral parenteral nutrition for patients undergoing esophagectomy for cancer: a pilot study of safety, surgical, and nutritional outcomes. Int J Surg. 2006;91:358-64.

36. Wu G, Liu Z, Wu Z. Perioperative artificial nutrition in malnourished gastrointestinal cancer patients. World J Gastroenterol. 2006;12(15):2441-4.

37. Duncan DG, Duncan DG, Beck SJ, Hood K, Johansen A. Using dietetic assistants to improve the outcome of hip fracture: a randomised controlled trial of nutritional support in an acute trauma ward. Age Ageing. 2005;35: 148-53. https://doi.org/10.1093/ageing/afj011.

38. Bilgin YM. Double-blind, randomized controlled trial on the effect of leukocytedepleted erythrocyte transfusions in cardiac valve surgery. Circulation. 2004; 109(22):2755-60. https://doi.org/10.1161/01.CIR.0000130162.11925.21.

39. van de Watering LM, Hermans J, Houbiers JG, et al. Beneficial effects of leukocyte depletion of transfused blood on postoperative complications in patients undergoing cardiac surgery: a randomized clinical trial. Circulation. 1998;97(6): 562-8 http://www.ncbi.nlm.nih.gov/pubmed/9494026. Accessed 4 Sept 2018.

40. Foss NB, Tange Kristensen M, Søe Jensen P, Palm H, Krasheninnikoff M, Kehlet $\mathrm{H}$. The effects of liberal versus restrictive transfusion thresholds on ambulation after hip fracture surgery. Transfusion. 2009;49(2):227-34. https:// doi.org/10.1111/j.1537-2995.2008.01967.x.

41. Kosmadakis N, Messaris E, Maris A, et al. Perioperative erythropoietin administration in patients with gastrointestinal tract cancer prospective randomized double-blind study. Annals of surgery. 2003;237(3):417 https:// v2dis-prod.evidencepartners.com/Generic/getAttachment2.php?id=225. Accessed 25 Oct 2017.

42. Lobo SM, Salgado PF, Castillo VG, et al. Effects of maximizing oxygen delivery on morbidity and mortality in high-risk surgical patients. Crit Care Med. 2000; 28(10):3396-404. https://doi.org/10.1097/00003246-200010000-00003. 
43. Meyhoff CS, Jorgensen LN, Wetterslev J, Christensen KB, Rasmussen LS. Increased long-term mortality after a high perioperative inspiratory oxygen fraction during abdominal surgery: follow-up of a randomized clinical trial. Anesth Analg. 2012;115(4):849-54. https://doi.org/10.1213/ANE. Ob013e3182652a51.

44. Antonelli M, Conti G, Bufi M, et al. Noninvasive ventilation for treatment of acute respiratory failure in patients undergoing solid organ transplantation. JAMA. 2000;283(2):235. https://doi.org/10.1001/jama.283.2.235.

45. Zhu GF, Wang DJ, Lui S, et al. Efficacy and safety of noninvasive positive pressure ventilation in the treatment of acute respiratory failure after cardiac surgery. Chin Med J. 2013;126(2009):4463-9. https://doi.org/10.3760/cma.j. issn.0366-6999.20131704.

46. Thielmann M, Kottenberg E, Kleinbongard P, et al. Cardioprotective and prognostic effects of remote ischaemic preconditioning in patients undergoing coronary artery bypass surgery: a single-centre randomised, double-blind, controlled trial. Lancet. 2013;382(17):597-604. https://doi.org/ 10.1016/S0140-6736(13)61450-6.

47. Qiu Z, Chen X, Xu M, et al. Evaluation of preoperative intra-aortic balloon pump in coronary patients with severe left ventricular dysfunction undergoing $\mathrm{OPCAB}$ surgery: early and mid-term outcomes. J Cardiothorac Surg. 2009;4(1):39. https://doi.org/10.1186/1749-8090-4-39.

48. Durmaz I, Yagdi T, Calkavur T, et al. Prophylactic dialysis in patients with renal dysfunction undergoing on-pump coronary artery bypass surgery. Ann Thorac Surg. 2003;75(02):859-64. https://doi.org/10.1016/S00034975(02)04635-0.

49. Van den Berghe $G$, Wouters $P$, Weekers $F$, et al. Intensive insulin therapy in critically ill patients. N Engl J Med. 2001;345(19) https://v2dis-prod.evidencepartners.com/ Generic/getAttachment2.php?id=1414. Accessed 25 Oct 2017.

50. Landoni G, Pisano A, Lomivorotov $V$, et al. Randomized evidence for reduction of perioperative mortality: an updated consensus process. J Cardiothorac Vasc Anesth. 2017;31(2):719-30. https://doi.org/10.1053/j.jvca. 2016.07.017.

51. Mclsaac DI, Wijeysundera DN, Huang A, Bryson GL, van Walraven C. Association of hospital-level neuraxial anesthesia use for hip fracture surgery with outcomes. Anesthesiology. 2018;128(3):480-91. https://doi.org/10.1097/ ALN.0000000000001899.

52. Neily J, Mills PD, Young-Xu Y, et al. Association between implementation of a medical team training program and surgical mortality. JAMA. 2010;304(15): 1693-700. https://www.ncbi.nlm.nih.gov/pubmed/20959579.

53. Meurisse M, Hamoir E, Defechereux T, et al. Bilateral neck exploration under hypnosedation: a new standard of care in primary hyperparathyroidism? Ann Surg. 1999;229(3):401-8 https://www.ncbi.nlm.nih.gov/pmc/articles/ PMC1191706/pdf/annsurg00003-0115.pdf. Accessed 2 Oct 2017.

54. Williamson PR, Altman DG, Bagley $\mathrm{H}$, et al. The COMET handbook: version 1. 0. Trials. 2017;18(S3):280. https://doi.org/10.1186/s13063-017-1978-4.

55. Grocott M, Myles P, Moonesinghe R, Boney O. Core Outcome Measures in Perioperative and Anaesthetic Care (COMPAC): Core Outcome Measures in Effectiveness Trials Initiative (COMET). 2017 http://www.comet-initiative.org/ studies/details/632. Published. Accessed 15 Dec 2017.

56. Shulman M, Myles P. Measuring perioperative outcome. Curr Opin Anaesthesiol. 2016;29(6):733-8. https://doi.org/10.1097/ACO. 0000000000000383.

57. Myles PS, Grocott MPW, Boney O, et al. Standardizing end points in perioperative trials: towards a core and extended outcome set. $\mathrm{Br} J$ Anaesth. 2016;116(5):586-9. https://doi.org/10.1093/bja/aew066.

58. National Confidential Enquiry into Patient Outcome and Death, Findley G. Knowing the risk: a review of the peri-operative care of surgical patients: summary:; 2011.

59. Mclsaac $D$, Lavallée $L T$, van Walraven $C$. A retrospective assessment of prognostication in 456,685 patients undergoing elective major non-cardiac surgery. Can J Anesth Can d'anesthésie. 2017;64(9):908-18. https://doi.org/ 10.1007/s12630-017-0909-x

60. Harsten A, Kehlet H, Toksvig-Larsen S. Recovery after total intravenous general anaesthesia or spinal anaesthesia for total knee arthroplasty: a randomized trial ${ }^{\dagger}$. This article is accompanied by editorial IV. Br J Anaesth. 2013;111(3):391-9. https://doi.org/10.1093/bja/aet104.

\section{Ready to submit your research? Choose BMC and benefit from:}

- fast, convenient online submission

- thorough peer review by experienced researchers in your field

- rapid publication on acceptance

- support for research data, including large and complex data types

- gold Open Access which fosters wider collaboration and increased citations

- maximum visibility for your research: over $100 \mathrm{M}$ website views per year

At BMC, research is always in progress.

Learn more biomedcentral.com/submissions 